
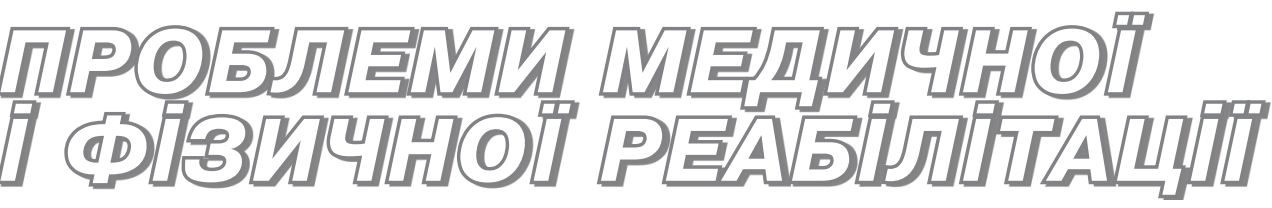

DOI:https://doi.org/10.32652/spmed.2019.2.51-58

\title{
Принципи створення та визначення ефективності системи заходів для подолання реабілітаційного нон-комплаєнсу пацієнтів 3 ожирінням
}

\author{
УДК 615.825:613.25
}

\section{М. Г. Аравіцька', О. Б. Лазарєва²}

1Прикарпатський національний університет імені Василя Стефаника, ЇваноФранківськ, Україна

${ }^{2}$ Національний університет фізичного виховання і спорту України, Київ, Україна

\begin{abstract}
Анотація. Мета. Визначити теоретичні передумови низького комплаєнсу (схильність до програми) у пацієнтів з ожирінням, сформувати шляхи його діагностики та створення системи подолання нон-комплаєнсу (небажання діяти за програмою) у процесі тривалої реабілітації з метою зниження маси тіла, провести практичне визначення іï ефективності. Методи. Для визначення величини реабілітаційного комплаєнсу та можливих шляхів його покращення за розробленою анкетою проведено розпитування 288 осіб другого зрілого віку з аліментарно-екзогенним ожирінням

I-III ступеня. Після цього проведено мотиваційно-ознайомчі лекції і здійснено повторне тестування, за результатами якого пацієнтів поділили на групи з високим комплаєнсом (для проведення реабілітаційних заходів для зменшення маси тіла та підтримки досягнутого рівня комплаєнсу) та з низьким комплаєнсом (група порівняння). Після річного впровадження реабілітаційної програми повторно визначали рівень комплаєнсу. Результати. Під час початкового опитування виявлено недостатній рівень комплаєнсу у більшості хворих ожирінням. Причинами цього найчастіше $€$ тривалий безсимптомний перебіг хвороби, дискомфортні відчуття на початкових етапах дієтотерапії голод, втома, слабке розуміння наслідків ожиріння, можливість додаткового фінансового навантаження. Методи корекції нон-комплаєнсу на всіх етапах корекції маси тіла доцільно проводити такими шляхами: освітні проекти, вплив на поведінку пацієнта; моніторинг комплаєнсу; індивідуальна адаптація програми реабілітації. На фоні застосування програми реабілітації із використанням заходів для утримання комплаєнсу на високому рівні досягнуто статистично значущого покращення індексу маси тіла. Висновок. До програм фізичної терапії хворих з ожирінням з метою підвищення їх ефективності доцільно включати заходи для зменшення реабілітаційного нон-комплаєнсу. Це призводить до збільшення відповідальності пацієнта та ступеня дотримання наданих рекомендацій, посилює самоконтроль, що особливо актуально в умовах тривалого зменшення маси тіла та пожиттєвого її утримання.

Ключові слова: фізична терапія, реабілітація, ожиріння, комплаєнс.
\end{abstract}

Principles of creating and determining the effectiveness of a system of measures to overcome the rehabilitation non-compliance of obese patients

M. G. Aravitska', O. B. Lazareva ${ }^{2}$

${ }^{1}$ Vasyl Stefanyk Precarpathian National University,

${ }^{2}$ National University of Physical Education and Sport of Ukraine

Abstract. Objective. To identify key approaches to diagnosing the causes of non-compliance in obese patients, to formulate ways to overcome it and to check their effective- 
ness in the program of physical therapy. Methods. In order to determine the magnitude of rehabilitation compliance and possible ways to improve it according to the developed questionnaire, 288 people of the second mature age with alimentary-exogenous obesity of I-III degree were interviewed. After that, motivational orientation lectures were held and repeated testing was conducted, according to the results of which the patients were divided into groups with high compliance (for rehabilitation measures to reduce body weight and maintain the achieved level of compliance) and with low compliance (comparison group). After a year-long implementation of the rehabilitation program, the level of compliance was re-determined. Results. At baseline, an insufficient level of compliance was found in most obese patients. The reasons for this are most often a prolonged asymptomatic course of the disease, uncomfortable sensations at the initial stages of diet therapy (hunger, fatigue), poor understanding of the effects of obesity, and the possibility of additional financial burden. Non-compliance correction methods at all stages of body weight correction should be carried out in the following ways: educational projects, influence on patient behavior; compliance monitoring; individual adaptation of the rehabilitation program. Against the background of the use of the rehabilitation program including measures to maintain compliance at a high level, a statistically significant improvement in body mass index was achieved. Conclusion. In order to increase the efficiency of physical therapy program for patients with obesity, it is advisable to include measures to reduce rehabilitation non-compliance. This leads to an increase in the patient's responsibility and the degree of compliance with the recommendations provided, strengthens self-control, which is especially important in conditions of prolonged weight loss and lifelong maintenance.

Keywords: physical therapy, rehabilitation, obesity, compliance.

Постановка проблеми. Ожиріння $€$ надзвичайно розповсюдженим захворюванням, що спричиняє високий ризик хвороб внутрішніх органів та передчасної смерті. Використання фізичної терапії (у вигляді розширення побутової та тренувальної рухової активності, модисрікації харчування) $\epsilon$ есрективним засобом покращення стану здоров'я хворих ожирінням при різних ступенях його тяжкості $[4,7]$. Проте у $95 \%$ випадків пацієнтам не вдається тривало утримувати досягнуту в процесі корекції масу тіла; більшість хворих повертаються до початкової маси тіла або перевищують їі $[7,14]$. Важливу роль у розвитку рецидивів захворювання відіграють пасивна позиція пацієнтів на етапі стабілізації зниженої маси тіла та недооцінка фахівцями і хворим особистісного фактора в процесі лікування ожиріння та у зміні способу життя в цілому $[8,9,13]$. Відсутність тривалого ефеекту утримання маси тіла свідчить про низький комплаєнс (схильність до програми) пацієнта, тому підвищення його рівня дозволяє збільшити ефективність не тільки нових програм корекції маси тіла, а й вже існуючих.

Вирішення питань недостатньої схильності до терапії (низький рівень комплаєнсу, нонкомплаєнсу) $\epsilon$ однією 3 актуальних проблем сучасної медицини і реабілітації і асоціюється з тривалою корекцією хронічних захворювань. Згідно $з$ висновками Всесвітньої організації охорони здоров'я (ВООЗ) низький комплаєнс $\epsilon$ однією з головних причин зменшення вираженості лікувального ефекту, істотного підвищення ймовірності розвитку ускладнень основного захворювання, що призводить до зниження якості життя хворих і збільшення витрат на лікування [6]. Ефективність реабілітації залежить від участі у процесі хворого, його готовності до тривалого лікування, правильної мотивації і володіння навичками, необхідними в повсякденному управлінні своїм захворюванням $[2,3,5]$.

Різноманітність клінічного перебігу ускладнень та асоційованих з ожирінням захворювань, що вимагають тривалої немедикаментозної корекції та застосування засобів фрізичної терапії, неоднорідність груп пацієнтів в умовах реабілітаційної практики, відсутність достатньої кількості методичних програм в системі оцінки реабілітаційного комплаєнсу спонукає шукати нові шляхи організації системи оцінки та підтримки схильності пацієнтів до реабілітації в умовах тривалого процесу зниження маси тіла.

Мета дослідження - визначити теоретичні передумови низького комплаєнсу у пацієнтів 3 ожирінням, сорормувати шляхи його діагностики та створення системи подолання нон-комплаєнсу у процесі тривалої реабілітації з метою зниження маси тіла, провести практичне визначення ії есрективності.

Матеріали та методи дослідження. У ході дослідження теоретично проаналізовано та узагальнено дані іноземних та вітчизняних джерел, присвячених проблемі медичного комплаєнсу, застосовано метод систематизації отриманої інформації для створення системи заходів для подолання нон-комплаєнсу у пацієнтів 3 ожирінням. Для перевірки ефеективності розробленої системи заходів проведено опитування 288 осіб 
другого зрілого віку (39,6 \pm 1,4 року) з аліментарно-екзогенним ожирінням I-III ступеня, діагностованим за індексом маси тіла: з ожирінням I ступеня - 65 жінок, 51 чоловік; з ожирінням II ступеня - 64 жінки, 43 чоловіка; з ожирінням III ступеня - 43 жінки, 31 чоловік.

Учасники відповідали за запитання розробленої нами анкети для визначення величини реабілітаційного комплаєнсу (у даному дослідженні терміни «комплаєнс» та «прихильність до реабілітації» використовували як синоніми). Їм пропонували оцінити за 10-бальною візуальною аналоговою шкалою (ВАШ) відповіді на запитання: «Оцінка можливості виконання рекомендацій та методик щодо зменшення маси тіла на даний момент» (основне запитання, відповідь на яке найповніше характеризувало рівень комплаєнсу); «Важливість контролю маси тіла»; «Впевненість у самоконтролі маси тіла» (0 - мінімально можливий параметр, 10 - максимально можливий). Рівень комплаєнсу оцінювали як низький (менше 6 балів), середній (6-8 балів), високий (9-10 балів). Пацієнта вважали достатньо комплаєнтним (готовим до модифрікації стилю життя та корекції ожиріння), починаючи з показника 6,5 бала [15].

Після проведення опитування на основі отриманих результатів здійснювали індивідуальні заходи щодо підвищення рівня комплаєнсу та заохочення до проходження програми фрізичної терапії. Після бесіди проводили повторне тестування, за результатами якого пацієнтів було розподілено на дві групи: групу поріВняння (з низьким рівнем комплаєнсу, представники якої не проходили програму реабілітації для зменшення маси тіла, але були поінформовані про ризики ожиріння; ознайомлені з основними принципами гіпокалорійного харчування та рухової активності при ожирінні - ГП1, ГП2, ГПЗ відповідно до ступеня ожиріння); основну групу (з високим рівнем комплаєнсу, представники якої проходили річну розроблену програму корекції маси тіла із застосуванням модифрікації харчування, зі збільшенням побутової та тренувальної рухової активності, лімфодренажних процедур, елементів поведінкової психокорекції, заходів для підтримки досягнутого рівня комплаєнсу - ОГ1, ОГ2, ОГЗ відповідно до ступеня ожиріння). Після впровадження реабілітаційної програми проводилось повторне визначення рівня комплаєнсу.

Комісія з біоетики ДВНЗ «Прикарпатський національний університет імені Василя Стефраника» схвалила застосування представлених методів дослідження. Всі учасники були інфрормовані про цілі, організацію, методи дослідження та підписали інформовану згоду щодо участі у ньому.
Отримані дані обробляли статистично за допомогою програм «Microsoft Excel» 5.0 та «Statistica» 6.0 for Windows. Для оцінки достовірності отриманих показників застосовували критерій Стьюдента. Критичний рівень значимості під час перевірки статистичних гіпотез у даному дослідженні - 0,05.

Робота виконана згідно з планом науководослідних робіт ДВНЗ «Прикарпатський національний університет імені Василя Стефраника» і $\epsilon$ фррагментом дослідження на тему: «Використання немедикаментозних засобів і природних фракторів для покращення фрізичного розвитку, функціональної і фрізичної підготовленості організму» (номер держреєстрації 0110U001671).

Результати дослідження. Вважаємо, що визначення рівня реабілітаційного комплаєнсу хворих 3 ожирінням доцільно проводити поетапно впродовж впровадження корегуючої програми: на початку програми зменшення маси тіла, під час іiі проведення та, наприкінці. Необхідно з'ясувати такі питання: самооцінка можливості виконання рекомендацій зі зменшення маси тіла (рівня комплаєнсу); можливості самоконтролю маси, важливості самоконтролю маси за 10-бальною візуальною аналоговою шкалою; причини низького комплаєнсу (невдалі попередні спроби схуднення, дискомфортні відчуття, фрінансові проблеми, низька інфоормованість щодо наслідків ожиріння тощо); переважний профріль проблеми ожиріння для визначення індивідуальних цілей реабілітації (косметична, медична, соціальна, особиста тощо); визначення інформованості про вплив ожиріння на стан здоров'я та методи його корекції; самоаналіз шляхів покращення комплаєнсу і підвищення шансів на повноцінне проходження програми реабілітації (адаптація до режиму дня, фрінансових можливостей, психоемоційна підтримка, вибір оптимальної тривалості програми, методи контролю, визначення цілей реабілітації). Наприкінці впровадження програми доцільно проводити ретроспективний аналіз комплаєнсу - які саме заходи були найефективнішими (контроль фрахівця, самоконтроль, задоволеність результатом, психологічна підтримка, тощо) для підтримки досягнутого рівня у кожного пацієнта - i враховувати це для визначення подальших цілей і принципів реабілітації.

Під час визначення вихідного рівня комплаєнсу в ході самооцінки можливості виконання рекомендації щодо зменшення маси тіла у осіб всіх ступенів ожиріння він був недостатній (менше 6,5 бала) (табл. 1), що свідчить про необхідність проведення відповідних заходів для підвищення ефективності тривалих реабілітаційних програм. 
Показник виконання рекомендацій був найменшим у пацієнтів з високим ступенем ожиріння. Важливість самоконтролю маси тіла на досить високому рівні відмічали всі пацієнти. Водночас впевненості у самоконтролі не визначено в жодній з груп; особливо критичним був показник пацієнтів з ожирінням III ступеня.

ВООЗ пропонує розділяти фрактори, що впливають на медичний комплаєнс, на такі п'ять груп: 1) пов'язані з пацієнтами, 2) пов'язані з фрахівцями та організацією системи охорони здоров'я, 3) лікарської терапії, 4) захворювання, 5) соціально-економічні [6]. Пропонуємо до застосування систему подолання нон-комплаєнсу пацієнтів з ожирінням на основі цієї класифрікації (табл. 2).

Рекомендуємо дотримуватись таких практичних рекомендацій для підтримки високого рівня комплаєнсу у пацієнтів з ожирінням продовж тривалої програми реабілітації:

- визначення коротко- та довготривалих цілей у SMART-форматі, постійне їх нагадування та динамічна корекція;
- проведення ознайомчих бесід та, по можливості, залучення родин пацієнта до участі та підтримки в процесі виконання програми реабілітації;

- виявлення та усунення неприємних відчуттів, які можуть спричинити передчасний вихід 3 програми ожиріння (голоду, втоми, пригнічення, відсутності психологічної підтримки з боку реабілітолога та родини);

- навчання методам самоконтролю стану здоров'я (маса тіла, артеріальний тиск, частота дихання, рівень втоми за шкалою Борга, суб'єктивні показники погіршення стану; застосування мобільних додатків для контролю визначення калорійності раціону та трекерів рухової активності) та самозвіту (електронний або письмовий щоденник харчування та рухової активності) з регулярною передачею інформації реабілітологу;

- створення раціону харчування згідно з цільовою калорійностю, але з конкретним вибором продуктів відповідно до фрінансових можливостей пацієнта;

ТАБЛИЦЯ 1 - Динаміка рівня реабілітаційного комплаєнсу пацієнтів з ожирінням під впливом заходів для його підвищення $(\bar{x} \pm S)$

\begin{tabular}{|c|c|c|c|c|}
\hline \multirow[b]{2}{*}{ Група пацієнтів } & \multirow[b]{2}{*}{$\begin{array}{l}\text { Кількість } \\
\text { осіб у групі }\end{array}$} & \multicolumn{3}{|c|}{ Рівень комплаєнсу на момент опитування за ВАШ, бали } \\
\hline & & $\begin{array}{c}\text { Самооцінка потенційної можливості } \\
\text { виконання (продовження виконання для) } \\
\text { рекомендацій щодо зменшення маси тіла }\end{array}$ & $\begin{array}{l}\text { Важливість } \\
\text { самоконтролю } \\
\text { маси тіла }\end{array}$ & $\begin{array}{l}\text { Впевненість } \\
\text { у самоконтролі } \\
\text { маси тіла }\end{array}$ \\
\hline \multicolumn{5}{|c|}{ Ожиріння I ступеня } \\
\hline Початкове обстеження & $\mathrm{n}=116$ & $5,88 \pm 0,15$ & $7,54 \pm 0,27$ & $6,03 \pm 0,10$ \\
\hline ГП1 після лекції & $\mathrm{n}=60$ & $6,23 \pm 0,11$ & $8,21 \pm 0,24^{\circ}$ & $6,15 \pm 0,23$ \\
\hline $\begin{array}{l}\text { ГП1 після річного } \\
\text { спостереження }\end{array}$ & $\mathrm{n}=60$ & $6,08 \pm 0,34$ & $8,04 \pm 0,47$ & $5,97 \pm 0,31$ \\
\hline ОГ1 після лекції & $n=56$ & $8,57 \pm 0,17^{\circ *}$ & $9,43 \pm 0,17^{\circ *}$ & $8,62 \pm 0,31^{\circ *}$ \\
\hline $\begin{array}{l}\text { ОГ1 після річної програми } \\
\text { ФТ }\end{array}$ & $\mathrm{n}=56$ & $9,25 \pm 0,42^{\bullet *}$ & $9,67 \pm 0,15^{*}$ & $9,41 \pm 0,10^{\bullet *}$ \\
\hline \multicolumn{5}{|c|}{ Ожиріння II ступеня } \\
\hline Початкове обстеження & $n=98$ & $4,38 \pm 0,28$ & $6,21 \pm 0,27$ & $4,12 \pm 0,20$ \\
\hline ГП2 після лекції & $\mathrm{n}=57$ & $5,27 \pm 0,12^{\circ}$ & $6,88 \pm 0,14^{\circ}$ & $4,86 \pm, 015^{\circ}$ \\
\hline $\begin{array}{l}\text { ГП2 після річного } \\
\text { спостереження }\end{array}$ & $\mathrm{n}=57$ & $6,38 \pm 0,25^{\bullet}$ & $7,22 \pm 0,28$ & $4,52 \pm 0,11$ \\
\hline ОГ2 після лекції & $\mathrm{n}=41$ & $7,65 \pm 0,12^{\circ *}$ & $8,35 \pm 0,14^{\circ *}$ & $7,81 \pm 0,31^{\circ *}$ \\
\hline $\begin{array}{l}\text { ОГ2 після річної програми } \\
\text { ФТ }\end{array}$ & $\mathrm{n}=41$ & $9,01 \pm 0,19 \bullet *$ & $9,54 \pm 0,28^{\bullet *}$ & $8,42 \pm 0,48^{*}$ \\
\hline \multicolumn{5}{|c|}{ Ожиріння III ступеня } \\
\hline Вихідний & $\mathrm{n}=74$ & $3,82 \pm 0,31$ & $6,08 \pm 0,16$ & $1,36 \pm 0,06$ \\
\hline ГПЗ після лекції & $\mathrm{n}=47$ & $5,52 \pm 0,18^{\circ}$ & $7,64 \pm 0,33^{\circ}$ & $3,71 \pm 0,19^{\circ}$ \\
\hline $\begin{array}{l}\text { ГПЗ після річного } \\
\text { спостереження }\end{array}$ & $\mathrm{n}=47$ & $6,72 \pm 0,36^{\bullet}$ & $8,87 \pm 0,12^{\bullet}$ & $4,03 \pm 0,15$ \\
\hline ОГЗ після лекції & $n=27$ & $7,01 \pm 0,21^{\circ *}$ & $7,23 \pm 0,28^{\circ}$ & $6,89 \pm 0,20^{\circ *}$ \\
\hline ОГЗ після річної програми ФТ & $n=27$ & $8,33 \pm 0,13^{\bullet *}$ & $9,07 \pm 0,35^{\bullet}$ & $8,44 \pm 0,37^{\bullet *}$ \\
\hline
\end{tabular}

Примітка: - статистично значуща різниця у порівнянні із відповідним показником до індивідуальної лекції для підвищення реабілітаційного комплаєнсу ( $<0,05)$; - статистично значуща різниця у порівнянні із відповідним вихідним показником до річного періоду спостереження/реабілітації ( $<<0,05)$; * - статистично значуща різниця у порівнянні із відповідним показником ГП (р < 0,05). 
ТАБЛИЦЯ 2 - Групи факторів, які впливають на комплаєнс, адаптовані до реабілітаційних потреб, та запропоновані методи їх подолання в рамках реабілітаційної програми для хворих з ожирінням

\begin{tabular}{|c|c|c|}
\hline $\begin{array}{l}\text { Категорія факторів, } \\
\text { які впливають } \\
\text { на комплаєнс } \\
\text { (за ВОО3, 2003) }\end{array}$ & $\begin{array}{c}\text { Зона впливу (за ВООЗ, 2003) [6] } \\
\text { з адаптацією до реабілітаційних } \\
\text { проблем }\end{array}$ & $\begin{array}{l}\text { Запропоновані методи вирішення } \\
\text { в рамках реабілітації пацієнтів } 3 \text { ожирінням }\end{array}$ \\
\hline \multirow[t]{3}{*}{$\begin{array}{l}\text { Соціальні та } \\
\text { економічні }\end{array}$} & Фінансове положення & $\begin{array}{l}\text { Вибір продуктів харчування згідно з фінансовими можливостями } \\
\text { Заміна тренувань у реабілітаційному закладі/спортивному або фітнес-залі } \\
\text { самостійними заняттями за складеною програмою } \\
\text { Інформування щодо можливості зменшення кількості вживаних ліків для } \\
\text { корекції супутніх станів - наслідків ожиріння (після відповідних консультацій) }\end{array}$ \\
\hline & Низький рівень культури & $\begin{array}{l}\text { Інформування пацієнта щодо впливу ожиріння на стан здоров'я } \\
\text { Інформування щодо механізму дії запропонованих засобів реабілітації на } \\
\text { ланки етіопатогенезу ожиріння }\end{array}$ \\
\hline & $\begin{array}{l}\text { Віддаленість від } \\
\text { реабілітаційного закладу }\end{array}$ & $\begin{array}{l}\text { Заміна тренувань у реабілітаційному закладі/спортивному або фітнес-залі } \\
\text { самостійними заняттями за складеною програмою } \\
\text { Використання засобів телемедицини (консультування, корекція } \\
\text { реабілітаційної програми, передача показників самоконтролю, відповіді } \\
\text { на запитання, листування за допомогою мобільних додатків та соціальних } \\
\text { мереж, онлайн-відеозв'язку та відеоконференцій) }\end{array}$ \\
\hline \multirow{2}{*}{$\begin{array}{l}\text { Системні (пов'язані } \\
\text { із системою } \\
\text { охорони здоров'я) }\end{array}$} & $\begin{array}{l}\text { Стосунки } \\
\text { «реабілітолог-пацієнт» }\end{array}$ & $\begin{array}{l}\text { Створення хороших міжособистістних стосунків на основі довіри, } \\
\text { партнерства, поваги }\end{array}$ \\
\hline & $\begin{array}{l}\text { Наявність реабілітаційних } \\
\text { установ }\end{array}$ & $\begin{array}{l}\text { Заміна тренувань у реабілітаційному закладі/спортивному або фрітнес-залі } \\
\text { самостійними заняттями за складеною програмою } \\
\text { Використання засобів телемедицини } \\
\text { Навчання методів самоконтролю стану здоров'я та самозвіту з регулярною } \\
\text { передачею інформації реабілітологу } \\
\text { Можливість проходження реабілітації у закладах різних фрорм власності за } \\
\text { розробленою індивідуальною схемою }\end{array}$ \\
\hline \multirow{4}{*}{$\begin{array}{l}\text { Пов'язані з } \\
\text { хворобою }\end{array}$} & Ступінь тяжкості симптомів & Індивідуальний підхід до складання реабілітаційної програми \\
\hline & Неприємні фрізичні відчуття & Індивідуальний підхід до складання реабілітаційної програми \\
\hline & Коморбідність & $\begin{array}{l}\text { Індивідуальний підхід до складання реабілітаційної програми } \\
\text { Консультація (за потреби) вузькоспеціалізованими фахівцями вторинної } \\
\text { ланки медичної допомоги }\end{array}$ \\
\hline & $\begin{array}{l}\text { Наявність ефективних засобів } \\
\text { реабілітації }\end{array}$ & $\begin{array}{l}\text { Включення до програми реабілітації засобів корекції маси тіла із доведеною } \\
\text { клінічною ефрективністю }\end{array}$ \\
\hline \multirow[t]{5}{*}{$\begin{array}{l}\text { Зумовлені } \\
\text { реабілітацією }\end{array}$} & Складність режиму & $\begin{array}{l}\text { Індивідуальний підхід до складання реабілітаційної програми } \\
\text { Інформування щодо необхідності дотримання наданих рекомендацій з } \\
\text { метою профрілактики та корекції ускладнень ожиріння }\end{array}$ \\
\hline & Тривалість реабілітації & $\begin{array}{l}\text { Індивідуальний підхід до складання реабілітаційної програми } \\
\text { Інформування щодо необхідності тривалого дотримання наданих } \\
\text { рекомендацій з метою профрілактики та корекції ускладнень ожиріння } \\
\text { Навчання методів самоконтролю стану здоров'я та самозвіту з регулярною } \\
\text { передачею інформації реабілітологу }\end{array}$ \\
\hline & $\begin{array}{l}\text { Неефективність проведених } \\
\text { реабілітаційних заходів }\end{array}$ & $\begin{array}{l}\text { 3'ясування причин неефективності або низької ефективності та їх корекція } \\
\text { Поточний контроль стану пацієнта з метою своєчасного виявлення } \\
\text { неефективності застосованих засобів } \\
\text { Включення до програми реабілітації засобів корекції маси тіла із доведеною } \\
\text { клінічною ефективністю } \\
\text { Інформування щодо необхідності дотримання наданих рекомендацій з } \\
\text { метою профілактики та корекції ускладнень ожиріння }\end{array}$ \\
\hline & $\begin{array}{l}\text { Ускладнений вибір засобів } \\
\text { реабілітації }\end{array}$ & $\begin{array}{l}\text { Індивідуальний підхід до складання реабілітаційної програми } \\
\text { Включення до програми реабілітації засобів корекції маси тіла із доведеною } \\
\text { клінічною ефрективністю }\end{array}$ \\
\hline & $\begin{array}{l}\text { Небажані ефекти засобів } \\
\text { реабілітації }\end{array}$ & $\begin{array}{l}\text { 3'ясування причин виникнення небажаних ефектів та їх індивідуальна корекція } \\
\text { Індивідуальний підхід до складання реабілітаційної програми }\end{array}$ \\
\hline \multirow[t]{2}{*}{$\begin{array}{l}\text { Зумовлені } \\
\text { особливостями } \\
\text { пацієнта }\end{array}$} & $\begin{array}{l}\text { Страх перед небажаними } \\
\text { ефектами реабілітаційних } \\
\text { заходів }\end{array}$ & $\begin{array}{l}\text { 3'ясування причин виникнення небажаних ефектів та їх індивідуальна } \\
\text { корекція } \\
\text { Індивідуальний підхід до складання реабілітаційної програми } \\
\text { Навчання методів самоконтролю стану здоров'я та самозвіту з регулярною } \\
\text { передачею інформації реабілітологу }\end{array}$ \\
\hline & $\begin{array}{l}\text { Передчасне припинення } \\
\text { реабілітації }\end{array}$ & $\begin{array}{l}\text { 3'ясування причин передчасного припинення реабілітації та їх нівелювання } \\
\text { (по можливості) } \\
\text { Індивідуальний підхід до складання реабілітаційної програми } \\
\text { Інформування щодо необхідності дотримання наданих рекомендацій з } \\
\text { метою профрілактики та корекції ускладнень ожиріння }\end{array}$ \\
\hline
\end{tabular}




\begin{tabular}{|c|c|c|}
\hline $\begin{array}{l}\text { Категорія фракторів, } \\
\text { які впливають } \\
\text { на комплаєнс } \\
\text { (за ВОО3, 2003) }\end{array}$ & $\begin{array}{c}\text { Зона впливу (за ВООЗ, 2003) [6] } \\
\text { з адаптацією до реабілітаційних } \\
\text { проблем }\end{array}$ & $\begin{array}{c}\text { Запропоновані методи вирішення } \\
\text { в рамках реабілітації пацієнтів } 3 \text { ожирінням }\end{array}$ \\
\hline & Необґрунтовані очікування & $\begin{array}{l}\text { Складання коротко- та довготривалих цілей реабілітації та їх дотримання у } \\
\text { SMART-фрорматі }\end{array}$ \\
\hline & Забудькуватість & $\begin{array}{l}\text { Складання графіку відвідування реабілітолога } \\
\text { Створення нагадувань щодо дотримання реабілітаційних заходів за } \\
\text { допомогою мобільних додатків } \\
\text { Ведення щоденника самоконтролю, самозвіт } \\
\text { Використання засобів телемедицини у спілкуванні із реабілітологом } \\
\text { Навчання методів самоконтролю стану здоров'я та самозвіту з регулярною } \\
\text { передачею інфрормації реабілітологу }\end{array}$ \\
\hline & Знання щодо захворювання & $\begin{array}{l}\text { Проведення ознайомчих бесід, лекцій щодо етіології, патогенезу, } \\
\text { клінічного перебігу ожиріння, його наслідків для здоров'я; шляхів впливу } \\
\text { запропонованих методів фрізичної терапії } \\
\text { Інформування щодо необхідності дотримання наданих рекомендацій з } \\
\text { метою профілактики та корекції ускладнень ожиріння пацієнтів та членів їх } \\
\text { родин }\end{array}$ \\
\hline
\end{tabular}

- адаптація принципів режимів харчування та рухової активності згідно з режимом праці та відпочинку пацієнта; створення програми індивідуальних тренувань у фрорматі відео, яке можна виконувати у зручний час;

- створення системи індивідуальних нагадувань та їх налаштування у смартфроні під контролем реабілітолога;

- навчання методам самозвіту (електронний або письмовий щоденник харчування та рухової активності) з передачею інфрормації реабілітологу;

- фрормування графріка особистих відвідувань реабілітаційного закладу для проміжного контролю та корекції програми мінімум один раз на місяць;

- використання засобів телемедицини (консультування, корекція реабілітаційної програми, передача показників самоконтролю, відповіді на запитання, листування за допомогою мобільних додатків та соціальних мереж, онлайнвідеозв'язку та відеоконференцій);

- акцентування уваги на позитивних змінах, досягнутих у процесі реабілітації, на покращенні самопочуття, зовнішнього вигляду, настрою, стану здоров'я, на розширенні функціональних резервів організму.

Аналіз рівнів комплаєнсу після річного періоду спостереження показав, пацієнти основних груп статистично значуще збільшили рівень згоди виконання рекомендацій і потенційно будуть продовжувати їх виконувати для досягнення цільової маси тіла (особи ОГ2 та ОГЗ) та підтримки отриманого результату (представники ОГ1) (табл. 1). Серед пацієнтів ГП статистично значущого результату покращення потенційного виконання рекомендацій показали представники ГП2 та ГП3; мінімального рівня, що характеризує дійсне їх виконання (6,5 бала), показали тільки особи з морбідним ожирінням. Важливість самоконтролю маси тіла в динаміці також зросла, особливо в осіб з ожирінням II-III ступеня. Впевненість у самоконтролі маси тіла на високому рівні виявили представники ОГ1, на середньому - ОГ2 та ОГЗ. У представників ГП цей параметр залишався на низькому рівні.

Дискусія. Теоретичний аналіз наукових літературних даних про проблему покращення стану здоров'я хворих з ожирінням показав, що нині поширеність даного захворювання набула розмірів пандемії, отже, її вирішення набуло надзвичайного значення в світовому масштабі [7, 14]. Встановлено, що обмеження калорійності, самоконтроль і навчання важливіші для зменшення маси тіла, ніж будь-який конкретний склад харчування, а при подальшому збільшенні маси тіла позитивний ефект на прозапальні маркери і біохімічні показники зберігається впродовж тривалого часу [9]. Дотримання рекомендацій фрізичного терапевта дозволяє покращити показники якості життя пацієнтів з ожирінням, збільшити їх рухову активність та стан здоров'я $[1,11]$. Представлене дослідження підтверджує наявні дані щодо гостроти проблеми корекції стану здоров'я хворих 3 ожирінням [4, 8, 14].

Головною медичного проблемою ведення пацієнтів із зайвою масою тіла $є$ те, що, незважаючи на доведені за допомогою рандомізованих обстежень методи зниження маси тіла (створення дефріциту калорій між надходженням та витратою) $[7,8,14]$, кількість даного контингенту збільшується. Отже, існують певні супутні фрактори, які ускладнюють перебіг реабілітаційних заходів. Вважаємо, що одним із таких фракторів 
$€$ комплаєнс - згода пацієнта до виконання рекомендацій фрахівця. Якщо проблемі медичного комплаєнсу з акцентом на прийом лікарських засобів надається певна увага $[6,9,10,12]$, то проблема реабілітаційного комплаєнсу залишається маловивченою [5], а дані щодо комплаєнсу пацієнтів з ожирінням взагалі відсутні. Тому введення заходів для підвищення рівня згоди виконання коригуючих фрізіотерапевтичних міроприємств $€$ принципово новим поглядом на зменшення маси тіла в рамках реабілітаційних програм.

Вважаємо, що методи корекції комплаєнсу $€$ важливими на всіх етапах корекції маси тіла. Зважаючи на серйозні наслідки нон-комплаєнсу пацієнтів щодо їх здоров'я і благополуччя, а також у зв'язку з додатковим економічним навантаженням на систему охорони здоров'я [6, 10], доцільно стимулювати комплаєнс за допомогою спеціальних заходів, спрямованих на підвищення безпеки пацієнтів і в той же час на зниження витрат на фрармакотерапію та усунення викликаних недотриманням режиму наслідків. Апробована нами система підвищення реабілітаційного комплаєнсу умовно складається 3 таких розділів: освітні проекти (навчання, інформування та консультування пацієнтів, особливо груп ризику нонкомплаєнсу); моніторинг комплаєнсу (щоденники пацієнтів, регулярний контроль основних показників стану з постійним контролем з боку реабілітолога); адаптація реабілітації (визначення коротко- та довготермінових цілей реабілітації, адаптація програми до потреб конкретного пацієнта); вплив на поведінку пацієнта (методи, що допомагають пацієнтам вчасно дотримуватись режиму харчування та рухової активності, сигнали мобільних додатків).

\section{Література}

1. Аравіцька М, Лазарєва О. Динаміка якості життя хворих з ожирінням під впливом програми фізичної реабілітації [Dynamics of the quality of life of obese patients under the influence of physical rehabilitation program]. Спортивна медицина і фозична реабілітація. 2017;1:72-8. Доступно на: http://nbuv.gov.ua/UJRN/smed_2017_1_12.

2. Данилов Д. Терапевтическое сотрудничество (комплаенс): содержание, понятия, механизмы формирования и методы оптимизации [Therapeutic collaboration (compliance): content, definitions, mechanisms of formation, optimization methods]. Неврология, нейропсихиатрия, психосоматика. 2014;2:4-12. DOI: http://dx.doi.org/10.14412/2074-2711-20142-4-12.

3. Котельникова А, Кукшина А. Психодиагностические аспекты приверженности к лечению в процессе медицинской реабилитации [Psychodiagnostic aspects of treatment adherence during medical rehabilitation]. Вопросы курортологии, фризиотерапии и лечебной фризической культуры. 2016;3:44-9. DOI: 10.17116/kurort201634-9]
Розподіл пацієнтів з ожирінням за рівнями реабілітаційного комплаєнсу $€$ доцільним пунктом корекції їх маси тіла, що може проводити фрізичний терапевт. Раннє виявлення групи пацієнтів, які після проведення первинних заходів не виявили достатнього рівня згоди на їх продовження в рамках програми фрізичної терапії, дозволяє, з одного боку, зекономити ресурси фахівця і реабілітаційного закладу, а з іншого первинно діагностує потенційних осіб, які потребують вузькоспеціалізованих заходів (психологічних втручань, медикаментозного лікування, баріатричного хірургічного лікування).

Отриманий в процесі проведеного дослідження результат свідчить, що просте інфрормування пацієнтів щодо ризиків та наслідків ожиріння, методів його корекції, без активних заходів для подолання нон-комплаєнсу, $€$ неефективним 3 точки зору дотримання рекомендацій фрізичного терапевта. Отже, представлений підхід $€$ доцільним до застосування в реабілітаційній практиці.

Висновки. До програм реабілітації хворих 3 ожирінням доцільно включати заходи для подолання нон-комплаєнсу, що призводить до збільшення відповідальності пацієнта та ступеня дотримання ним наданих рекомендацій, посилює самоконтроль, що актуально в умовах тривалого зменшення маси тіла та пожиттєвого її утримання на досягнутому рівні.

Перспективи подальшого дослідження полягають у визначенні впливу розробленої системи реабілітації із подоланням нон-комплаєнсу на клініко-фрізіологічні показники стану здоров'я пацієнтів з ожирінням.

Автори заявляють про відсутність конфлікту інтересів.

4. Седлецкий Ю. Современные методы лечения ожирения. Руководство для врачей [Modern methods of treating obesity. A guide for doctors]. Санкт-Петербург: Элби-СПб, 2007. 415 c.

5. Чеховська М. Комплаєнс як запорука позитивного ефректу у процесі фрізичної реабілітації [Compliance as a pledge of a positive effect in the process of physical rehabilitation]. У зб.: Сучасні тенденції у практиці й освіті з фрізичної терапії: тези доп. міжнар. наук. семінару. Львів: ЛДУФК, 2016; с. 71-3. Доступно на: http://repository.Idufk.edu. ua/bitstream/34606048/6592/1/M.\%20Чеховська.pdf

6. Adherence to Long-Term Therapies: Evidence for Action. New-York, WHO. 2003. Available from: http://whqlibdoc.who.int/ publications/2003/ 9241545992.pdf.

7. Amundson D, Djurkovic S, Matwiyoff G.The obesity paradox. Critical Care Clinics. 2010;26(4):583-96. DOI: 10.1016/j. ccc.2010.06.004. (2010)

8. Cefalu WT, Bray GA, Home PD, Garvey WT, Klein $\mathrm{S}$, Pi-Sunyer FX, et al. Advances in the Science, Treatment, 
and Prevention of the Disease of Obesity: Reflections From a Diabetes Care Editors' Expert Forum. Diabetes Care. 2015;38(8): 1567-82.

9. Cesa GL, Manzoni GM, Bacchetta M, Castelnuovo G, Conti S, Gaggioli A, et al. Virtual reality for enhancing the cognitive behavioral treatment of obesity with binge eating disorder: randomized controlled study with one-year follo-wup. Journal of medical Internet research. 2013;15(6):113. DOI: 10.2196/jmir.2441.

10. Jin J, Sklar GE, Oh MNS, Li SC. Factors affecting therapeutic compliance: A review from the patient's perspective. Therapeutics and Clinical Risk Management. 2008;(1):269-86.

11. Lazareva O, Aravitska M, Andrieieva O, Galan Y, Dotsyuk L. Dynamics of physical activity status in patients with grade I-III obesity in response to a physical rehabilitation program. Journal of Physical Education and Sport. 2017;17(3):1960-5. DOI:10.7752/jpes.2017.03193

helenkaL972@gmail.com
12. Stewart K, George J, Mc Namara KP, Jackson SL, Peterson GM, Bereznicki LR, et al. A multifaceted pharmacist intervention to improve antihypertensive adherence: a clusterrandomized, controlled trial (HAPPy trial). Journal of clinical pharmacy and therapeutics. 2014;39(5):527-34. DOI: 10.1111/ jcpt.12185.

13. Sturgiss EA, Sargent GM, Haesler E, Rieger E, Douglas $\mathrm{K}$. Therapeutic alliance and obesity management in primary care - a cross-sectional pilot using the Working Alliance Inventory. Clinical Obesity. 2016;6(6):376-9. DOI:10.1111/cob.12167.

14. World Health Organization. Obesity: preventing and managing the global epidemic. Report of a WHO Consultation (WHO Technical Report Series 894). Available from:http://www. who.int/nutrition/publications/obesity/WHO TRS 894/en

15. Zimmerman GL, Olsen CG, Bosworth MF. A 'stages of change' approach to helping patients change behavior. American family physician. 2000;61(5):1409-16.

Надійшла 28.10.2019 